\title{
Meningiomas of the upper and middle part of the clivus and surrounding structures: early and long-term outcome
}

\section{Bezpośrednie i odległe wyniki leczenia oponiaków górnej i środkowej częśi stoku oraz otaczajacych struktur}

Piotr Ładziński', Henryk Majchrzak', Wojciech Kaspera', Mariusz Maliszewski', Krzysztof Majchrzak', Michał Tymowski', Piotr Adamczyk', Bartłomiej Błaszczyk', Aleksandra Ślaska-Kaspera²

${ }^{1}$ Katedra i Oddział Kliniczny Neurochirurgii w Sosnowcu, Śląski Uniwersytet Medyczny w Katowicach

${ }^{2}$ Katedra i Klinika Laryngologii, Ślq̨ski Uniwersytet Medyczny w Katowicach

Neurologia i Neurochirurgia Polska 2013; 47, 4: 332-344

DOI: 10.5114/ninp.2013.36758

\begin{abstract}
Background and purpose: Meningiomas of the upper and middle parts of the clivus and surrounding structures are removed using petrosal approaches: anterior, posterior, combined and complete. The purpose of this study is to show the results of treatment of these meningiomas and to present our interpretation of the treatment strategy.

Material and methods: Twenty-six patients ( 17 women, 9 men) were included in the study. The neurological status of the patients was assessed before and after surgery as well as at the conclusion of the treatment. The following measurements and data were collected and recorded: approximate volume of the treated lesion, its relation to large blood vessels, cranial nerves and the brainstem, as well as tumour consistency and vascularisation.

Results: Symptoms duration ranged from 1 to 60 months (median: 16 months). In $57.7 \%$ of patients, imbalance was the predominant sign. Less frequent symptoms were: headaches, dysacusis and hemiparesis. Approximate volumes of the tumours ranged from 4 to $65 \mathrm{~mL}$ (mean: $32 \mathrm{~mL}$ ). Total or subtotal resection was achieved in $73.1 \%$ of patients. The patients' performance improved postoperatively in $34.5 \%$, remained unchanged in $46.2 \%$ and deteriorated in $11.5 \%$ of patients. Two $(7.8 \%)$ patients died after the surgery.
\end{abstract}

\section{Streszczenie}

Wstęp i cel pracy: Oponiaki górnej i środkowej części stoku oraz otaczających struktur są leczone $\mathrm{z}$ wykorzystaniem dostępów skalistych: przedniego, tylnego, złożonego i całkowitego. Celem niniejszej pracy jest przedstawienie własnych wyników leczenia powyższych oponiaków i własnej interpretacji strategii tego leczenia.

Materiał i metody: Analizie poddano grupę 26 chorych, wśród których było 17 kobiet i 9 mężczyzn. Ocenie podlegał stan neurologiczny chorych przed rozpoczęciem leczenia, po operacji i po zakończeniu leczenia oraz zmiany ich aktywności życiowej. Określano przybliżoną objętość operowanych guzów, ich stosunek do dużych naczyń, nerwów czaszkowych i pnia mózgu, jak również konsystencję i stopień unaczynienia.

Wyniki: Długość wywiadu wahała się od 1 do 60 miesięcy (mediana: 16 miesięcy). W 57,7\% przypadków wiodącym objawem były zaburzenia równowagi. Rzadziej występowały bóle głowy, niedosłuch i niedowład połowiczy. Przybliżona objętość usuniętych guzów wahała się od 4 do $65 \mathrm{~cm}^{3}$ (średnia: $32 \mathrm{~cm}^{3}$ ). W 73,1\% przypadków przeprowadzone resekcje były doszczętne lub z niewielkimi pozostałościami guzów. Aktywność życiowa leczonych w 34,6\% poprawiła się, w 46,2\% nie zmieniła się, w $11,5 \%$ nastąpiło jej pogorszenie, a 7,8\% leczonych zmarło.

Correspondence address: dr hab. n. med. Piotr ładziński, Katedra i Oddział Kliniczny Neurochirurgii, Śląski Uniwersytet Medyczny w Katowicach, Wojewódzki Szpital Specialistyczny nr 5 im. św. Barbary, Pl. Medyków 1, 41-200 Sosnowiec, tel.: + 323682 024, fax: + 323682 550, e-mail: sekr_nch@wss5.pl

Received: 18.01.2012; accepted: 27.07.2012 
Conclusions: The use of petrosal approaches in the surgical treatment of meningiomas of the upper and middle parts of the clivus and the surrounding structures facilitates good or at least satisfactory neurological outcome with a high proportion of complete resections and relatively low mortality.

Key words: clivus, petrous pyramid, meningioma, microsurgery, skull base surgery.

\section{Introduction}

Attachments of the meningiomas of the upper and middle parts of the clivus usually cross petro-occipital and spheno-petrosal synchondroses, thus substantiating the term petroclival or sphenopetroclival meningiomas [1-3]. Nonetheless, these tumours often extend beyond the clivus and petrous pyramid; for that reason the authors decided to call them meningiomas of the upper and the middle parts of the clivus and surrounding structures (CMs). Median localization of the attachments of these meningiomas in relation to trigeminal impression, internal acoustic meatus and jugular foramen enables their discrimination from petrosal meningiomas, which are also called meningiomas of the cerebellopontine angle $[4,5]$. The tumours in question displace cranial nerves laterally while being entangled in them, which makes them more difficult to dissect $[6,7]$. Importantly, CMs ought to be differentiated from meningiomas with an attachment to the tentorial in-
Wnioski: Stosowanie dostępów skalistych w operacyjnym leczeniu oponiaków górnej i środkowej części stoku oraz otaczających struktur pozwala na osiaganie przez chorych dobrego, względnie zadowalającego stanu neurologicznego, przy dużym odsetku doszczętnych resekcji i stosunkowo małej śmiertelności.

Słowa kluczowe: stok, piramida kości skroniowej, oponiak, mikrochirurgia, chirurgia podstawy czaszki.

cisure, Meckel cave or jugular foramen. Moreover, meningiomas of the anterior part of the cranio-cervical junction that encompass the lower part of the clivus $[2,8]$ form another, separate group of tumours. Barnett et al. [9], while discussing the surgical strategy for CMs, stress that treatment should be 'as simple as possible, as cautious as possible and as extensive as necessary'. It is still a challenge to fulfil this principle. The aim of the present study is to present our results of treatment of the above-mentioned group of meningiomas and our interpretation of the treatment strategy.

\section{Material and methods}

CMs have been treated in the Clinical Department of Neurosurgery in Sosnowiec since May 1999. We performed a retrospective analysis on a group of 26 patients (17 women and 9 men) aged 31 to 68 years who underwent surgery between May 1999 and May 2010. Five

Table 1. Changes in neurological abnormalities that occurred prior to the surgical treatment in 26 patients

\begin{tabular}{|c|c|c|c|}
\hline Symptom & $\begin{array}{c}\text { Examination } \\
\text { on admission (\%) }\end{array}$ & $\begin{array}{c}\text { Examination } \\
\text { on discharge (\%) }\end{array}$ & $\begin{array}{c}\text { Follow-up } \\
\text { examination (\%) }\end{array}$ \\
\hline Headache & 38.5 & 0 & 0 \\
\hline Disequilibrium & 57.7 & 30.8 & 15.4 \\
\hline Hemiparesis & 23.1 & 15.4 & 7.8 \\
\hline Cerebellar ataxia & 15.4 & 11.5 & 3.8 \\
\hline Third or fourth nerve palsy or paresis & 7.8 & 7.8 & 3.8 \\
\hline Sixth nerve palsy or paresis & 30.8 & 26.9 & 15.4 \\
\hline Decreased sensation in the distribution of the ophthalmic nerve & 19.2 & 19.2 & 15.4 \\
\hline Decreased sensation in the distribution of the maxillary nerve & 26.9 & 16.9 & 19.2 \\
\hline Neuralgia in the distribution of the maxillary nerve & 15.4 & 3.8 & 0 \\
\hline Neuralgia in the distribution of the mandibular nerve & 11.5 & 0 & 0 \\
\hline Seventh nerve palsy or paresis & 15.4 & 15.4 & 7.8 \\
\hline Unilateral hypoacusis or deafness & 38.5 & 38.5 & 35.5 \\
\hline Ninth or tenth nerve palsy or paresis & 7.8 & 7.8 & 3.8 \\
\hline
\end{tabular}


distinct approaches were implemented as part of treatment: anterior petrosal approach (7 cases), posterior petrosal approach (5 cases), combined petrosal approach, i.e. a combination of both petrosal approaches (5 cases), complete petrosal approach (6 cases), or a two-stage approach that combines fronto-temporo-orbito-zygomatic approach and subsequently posterior petrosal approach (3 cases).

Neurological status of the patients at the beginning of the treatment, at discharge and at the end of rehabilitation (Tables 1 and 2) along with the changes of everyday performance assessed with the Karnofsky scale (Table 3) were analysed. The volumes of the tumours were approximated with a formula for a rotational ellipsoid: volume $=\Pi / 6(x \cdot y \cdot z)$ where $x, y$ and $z$ represent the largest diameter in sagittal, coronal and axial planes, respectively, based on magnetic resonance imaging (MRI). Detailed tumour topography evaluation encompassed the relationship of tumours to large vessels, cranial nerves and brainstem as well as their consistency and vascularity. The extensiveness of resection was as- sessed intraoperatively and verified with postoperative MRI examination performed 3 months after surgery; Simpson scale was subsequently appointed. Distributions of continuous data (catamnesis time, follow-up time and tumour volumes) were analysed with the ShapiroWilk test. Variables without normal distribution were presented with median and upper and lower quartiles. Variables with normal distribution were presented with mean and standard deviations (SD).

\section{Results}

The time of catamnesis for all of the patients with $\mathrm{CM}$ varied from 1 to 60 months (median: 16 months, lower quartile: 5 months, upper quartile: 36 months). Fifteen patients $(57.7 \%)$ presented with gait disturbances. This symptom was the earliest and the most prevalent one. Approximately $38.5 \%$ of cases (10 patients) presented with headache, unilateral hypoacusis or unilateral deafness. Rarely hemiparesis, or disturbances of cranial nerves

Table 2. Changes in the neurological status that occurred after surgical treatment in 24 patients

\begin{tabular}{|lccc|}
\hline Symptom & $\begin{array}{c}\text { Examination } \\
\text { on admission (\%) }\end{array}$ & $\begin{array}{c}\text { Examination } \\
\text { on discharge (\%) }\end{array}$ & $\begin{array}{c}\text { Follow-up } \\
\text { examination (\%) }\end{array}$ \\
\hline Consciousness disturbances & 16.6 & 0 & 0 \\
\hline Respiratory insufficiency & 16.6 & 0 & 16.6 \\
\hline Hemiparesis or hemiplegia & 37.5 & 33.3 & 0 \\
\hline Aphasia & 12.5 & 4.2 & 0 \\
\hline Temporal lobe oedema & 50 & 0 & 0 \\
\hline Brainstem oedema & 20.8 & 0 & 0 \\
\hline Hydrocephalus & 16.6 & 0 & 4.2 \\
\hline Disequilibrium & 20.8 & 12.5 & 0 \\
\hline Cerebellar ataxia & 16.6 & 12.5 & 29.2 \\
\hline Third or fourth nerve palsy or paresis & 16.6 & 16.6 & 12.5 \\
\hline Sixth nerve palsy or paresis & 58.3 & 58.3 & 16.6 \\
\hline Decreased sensation in the distribution of the ophthalmic nerve & 12.5 & 12.5 & 16.6 \\
\hline Decreased sensation in the distribution of the maxillary nerve & 20.8 & 20.8 & 41.7 \\
\hline Decreased sensation in the distribution of the mandibular nerve & 20.8 & 20.8 & 12.5 \\
\hline Seventh nerve palsy or paresis & 66.7 & 54.2 & 4.2 \\
\hline Unilateral hypoacusis or deafness & 25 & 25 & 0 \\
\hline Ninth or tenth nerve palsy or paresis & 8.3 & 4.2 & 0 \\
\hline Liquorrhoea from the wound & 16.6 & 0.3 & 0 \\
\hline Wound infection & 0.3 & 0 \\
\hline
\end{tabular}


Table 3. Tumour volume and topography, surgical approach, Simpson scale grading of the completeness of resection and assessment of functional capacity of patients according to Karnofsky performance scale

\begin{tabular}{|c|c|c|c|c|c|c|c|}
\hline $\begin{array}{l}\text { Patient's } \\
\text { number } \\
\text { and } \\
\text { initials }\end{array}$ & $\begin{array}{l}\text { Tumour } \\
\text { topography }\end{array}$ & $\begin{array}{c}\text { Tumour } \\
\text { volume } \\
\left(\mathrm{cm}^{3}\right)\end{array}$ & Approach & $\begin{array}{l}\text { Completeness } \\
\text { of resection }\end{array}$ & $\begin{array}{l}\text { Examination } \\
\text { on admission }\end{array}$ & $\begin{array}{l}\text { Examination } \\
\text { on discharge }\end{array}$ & $\begin{array}{l}\text { Follow-up } \\
\text { examination }\end{array}$ \\
\hline 1 - P.M. & $\begin{array}{l}\text { uc, mc, pp, } \\
\text { Mc, tn }\end{array}$ & 45.120 & $\mathrm{CbP}$ & II & 80 & 70 & 80 \\
\hline 2 - K.M. & $\mathrm{mc}, \mathrm{pp}$ & 21.475 & $\mathrm{PP}$ & II & 80 & 80 & 80 \\
\hline 3 -H.T. & $\mathrm{uc}, \mathrm{pp}, \mathrm{Mc}$ & 26.695 & $\mathrm{AP}$ & II & 80 & 70 & 90 \\
\hline 4 - I.S. & uc, mc, pp & 64.974 & $\mathrm{CpP}$ & II & 60 & 60 & 70 \\
\hline 5 - P.S. & uc, pp & 8.540 & $\mathrm{AP}$ & II & 90 & 70 & 80 \\
\hline $6-$ S.K. & uc, pp, tn & 19.563 & $\mathrm{AP}$ & IV & 60 & death & - \\
\hline 7 - T.J. & $\begin{array}{c}\text { uc, pp, } \\
\text { Mc, cs, tn }\end{array}$ & 18.347 & $\mathrm{AP}$ & IV & 60 & 40 & 60 \\
\hline 8 - J.P. & $\mathrm{uc}, \mathrm{mc}, \mathrm{pp}$ & 38.624 & $\mathrm{CpP}$ & II & 80 & 40 & 50 \\
\hline 9 - E.S. & $\mathrm{mc}, \mathrm{pp}$ & 10.125 & $\mathrm{PP}$ & II & 80 & 80 & 80 \\
\hline 10 - A.M. & uc, mc, pp & 61.482 & $\mathrm{CpP}$ & II & 80 & 50 & 80 \\
\hline 11 - B.B. & $\begin{array}{l}\text { uc, mc, pp, } \\
\text { Mc, tn, if }\end{array}$ & 59.742 & $\begin{array}{l}\text { FTOZA } \\
\text { PP }\end{array}$ & $\begin{array}{l}\text { IV } \\
\text { II }\end{array}$ & $\begin{array}{l}70 \\
80\end{array}$ & $\begin{array}{l}60 \\
60\end{array}$ & $\begin{array}{l}80 \\
80\end{array}$ \\
\hline 12 - T.L. & $\begin{array}{l}\mathrm{uc}, \mathrm{mc}, \mathrm{pp} \\
\mathrm{Mc}, \mathrm{cs}, \mathrm{tn} \text {, if }\end{array}$ & 42.690 & $\begin{array}{c}\text { FTOZA } \\
\text { PP }\end{array}$ & $\begin{array}{l}\text { IV } \\
\text { II }\end{array}$ & $\begin{array}{l}60 \\
80\end{array}$ & $\begin{array}{l}60 \\
70\end{array}$ & $\begin{array}{l}70 \\
80\end{array}$ \\
\hline 13 - E.S. & uc, mc, pp, Mc & 59.348 & $\mathrm{CpP}$ & IV & 90 & death & - \\
\hline 14 - I.M. & $\mathrm{mc}, \mathrm{pp}$ & 4.284 & $\mathrm{PP}$ & II & 80 & 80 & 90 \\
\hline 15 - D.K. & $\begin{array}{c}\mathrm{uc}, \mathrm{mc}, \mathrm{pp} \\
\mathrm{Mc}, \mathrm{cs}, \mathrm{tn}, \mathrm{ss}\end{array}$ & 35.834 & $\mathrm{CpP}$ & IV & 80 & 70 & 80 \\
\hline 16 - P.D. & uc, pp, tn & 12.064 & $\mathrm{AP}$ & II & 80 & 60 & 80 \\
\hline 17 - J.B. & uc, mc, pp & 24.640 & $\mathrm{CpP}$ & II & 70 & 60 & 80 \\
\hline $18-$ Z.K. & $\begin{array}{l}\mathrm{uc}, \mathrm{mc}, \mathrm{pp} \\
\mathrm{Mc}, \mathrm{cs}, \mathrm{tn}\end{array}$ & 41.625 & $\mathrm{CbP}$ & II & 70 & 70 & 80 \\
\hline 19 - M.K. & $\begin{array}{l}\mathrm{uc}, \mathrm{mc}, \mathrm{pp} \\
\mathrm{Mc}, \mathrm{cs}, \mathrm{tn}\end{array}$ & 36.254 & $\mathrm{CbP}$ & III & 90 & 80 & 80 \\
\hline $20-$ K.B. & $\mathrm{mc}, \mathrm{pp}$ & 20.948 & $\mathrm{PP}$ & IV & 80 & 70 & 80 \\
\hline 21 - K.M. & $\begin{array}{l}\mathrm{uc}, \mathrm{mc}, \mathrm{pp} \\
\mathrm{Mc}, \mathrm{cs}, \mathrm{tn}\end{array}$ & 50.014 & $\mathrm{CbP}$ & IV & 60 & 50 & 80 \\
\hline 22 - M.T. & $\begin{array}{l}\text { uc, mc, pp, } \\
\text { tn, if }\end{array}$ & 53.840 & $\begin{array}{l}\text { FTOZA } \\
\text { PP }\end{array}$ & $\begin{array}{l}\text { IV } \\
\text { II }\end{array}$ & $\begin{array}{l}80 \\
80\end{array}$ & $\begin{array}{l}60 \\
70\end{array}$ & $\begin{array}{l}70 \\
90\end{array}$ \\
\hline 23 - P.L. & uc, pp & 7.424 & $\mathrm{AP}$ & II & 90 & 90 & 90 \\
\hline $24-$ A.S. & $\mathrm{mc}, \mathrm{pp}$ & 22.573 & $\mathrm{PP}$ & II & 80 & 70 & 80 \\
\hline 25 - M.M. & $\mathrm{uc}, \mathrm{mc}, \mathrm{pp}$ & 32.924 & $\mathrm{CbP}$ & II & 90 & 80 & 90 \\
\hline 26 -A.T. & $\begin{array}{c}\text { uc, pp, } \\
\text { Mc, cs, tn }\end{array}$ & 14.538 & $\mathrm{AP}$ & IV & 80 & 70 & 80 \\
\hline
\end{tabular}

Topography: uc-upper clivus, mc - middle clivus, pp-petrous pyramid, Mc-Meckel's cave,

cs - cavernous sinus, tn - tentorial incisure, if - interpeduncular fossa, ss - sphenoid sinus.

Surgical approach: $A P$ - anterior petrous, $P P$ - posterior petrous, $C b P$ - combined petrous, $C p P$ - complete petrous, FTOZA - fronto-temporo-orbito-zygomatic approach 
(CN) III to $\mathrm{X}$ were found. Full neurological symptomatology prior to the treatment as well as its changes during the treatment is presented in Table 1.

Tumours encompassed eight distinct anatomical regions: upper part of the clivus $(80.8 \%, 21$ patients), middle part of the clivus $(73.1 \%, 19$ patients), petrous pyramid (100\%, 26 patients), Meckel cave and tentorial incisure $(42.3 \%, 11$ patients), cavernous sinus $(26.9 \%$, 7 patients), interpeduncular fossa (11.5\%, 3 patients) and sphenoid sinus (3.8\%, 1 patient) (Figs. 1-5).

Topography of particular tumours is summarized in Table 3. Average volume of the tumours varied from 4 to $65 \mathrm{~cm}^{3}$ (mean: $32 \mathrm{~cm}^{3}$, SD: $18 \mathrm{~cm}^{3}$ ).

All of the tumours were adjacent to the brainstem and dislocated it. In 4 cases, the arachnoid was missing and tumours were adherent to the pia of the brainstem. Additionally, in one of these cases preoperative MRI showed brainstem oedema. This patient presented with hemiparesis. Nine patients showed hemiplegia or hemiparesis or else deterioration of preoperative deficits after surgery; these symptoms subsided in 5 cases. All of the tumours were also adjacent to the spino-basal vasculature or their branches. Adhesions between tumours and vessels were concomitant with their adhesions to the brainstem pia. Only rarely were they found independently.

Similarly, all of the tumours were adjacent to the cranial nerves. A direct contact without adhesions was found for all of the nerves from CN II to CN XI. The ones most commonly involved were: trochlear nerve, abducens nerve, facial nerve and vestibulocochlear nerve. Likewise, adhesions between the tumour and cranial nerves were noted for the $\mathrm{CN} \mathrm{V}$ to XI with the trigeminal nerve most commonly involved. Cranial nerves $\mathrm{V}$ to VIII sometimes were encased in the tumour, predominantly the abducens nerve. Neurological deficits related to the injury of CN III to IX occurred after surgery and usually involved the facial nerve $(66.7 \%$, 16 patients) and abducens nerve (58.3\%, 14 patients). During follow-up, these symptoms diminished and were present in $41.7 \%$ (10 patients) and $29.2 \%$ (7 patients), respectively. Iatrogenic injures of other cranial nerves did not exceed $16.6 \%$ (4 patients) in follow-up.

The most severe complications of the surgery were consciousness and ventilation disturbances $(16.6 \%$, 4 patients). These patients required intensive care with mechanical ventilation and barbiturates. Half of the patients presented with postoperative temporal lobe oedema of various grades. Five of them showed brainstem oedema as well. One of them died owing to the symptoms of brainstem insufficiency. Another patient in our cohort succumbed to circulatory insufficiency that was present prior to the surgery and rapidly deteriorated afterwards. Full neurological symptomatology that presented following surgery along with its changes during follow-up is summarized in Table 2.
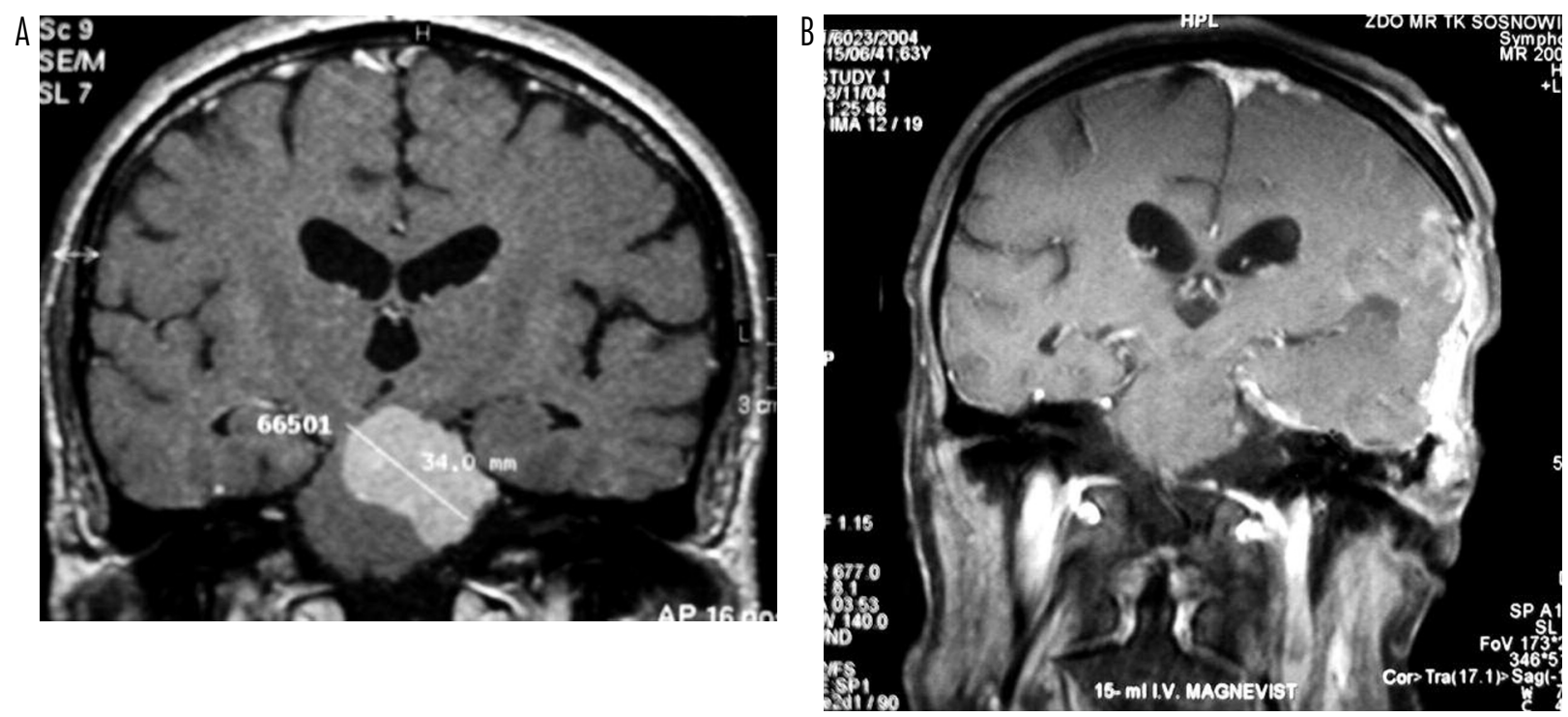

Fig. 1. Meningioma of upper part of the clivus and petrous pyramid on the left spanning up to the tentorial incisure (patient no. 16, P.D., aged 63). Patient presented with disequilibrium and left-sided hemiparesis. Tumour volume $12 \mathrm{~cm}^{3}$. Anterior petrosal approach was implemented with radical resection of the tumour and coagulation of attachment. Postoperative oedema of the temporal lobe and significant aggravation of the hemiparesis was found that subsequently subsided to the preoperative level. Follow-up time - 81 months; (A) preoperative coronal MRI; (B) postoperative coronal MRI 

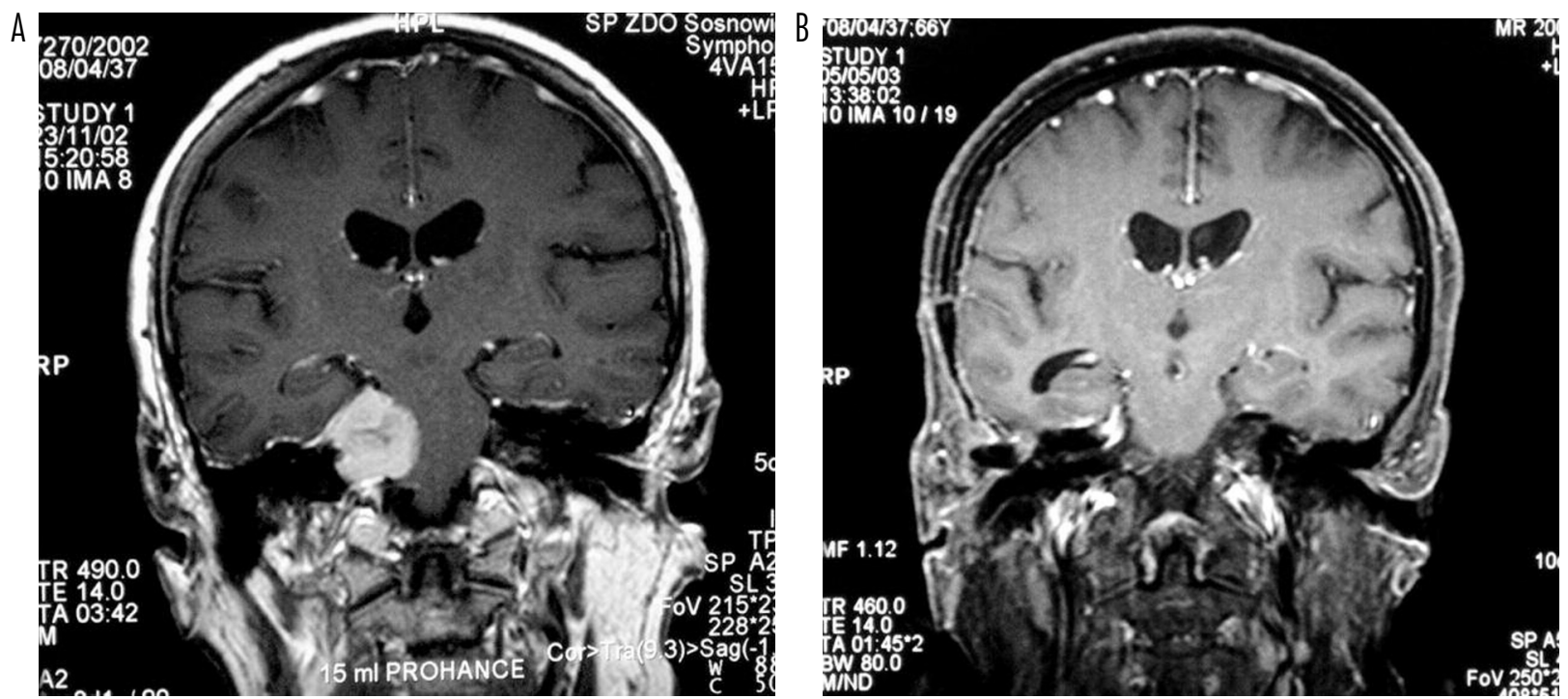

Fig. 2. Meningioma of middle part of the clivus and petrous pyramid on the right (patient no. 9, E.S., aged 65). Patient presented with disequilibrium and unilateral hypoacusis. Tumour volume $10 \mathrm{~cm}^{3}$. Posterior petrosal approach was implemented with radical resection of the tumour and coagulation of attachment. Postoperative period uneventful; however, neurological status remained unchanged when compared to preoperative examination. Follow-up time - 81 months; (A) preoperative coronal MRI, (B) postoperative coronal MRI
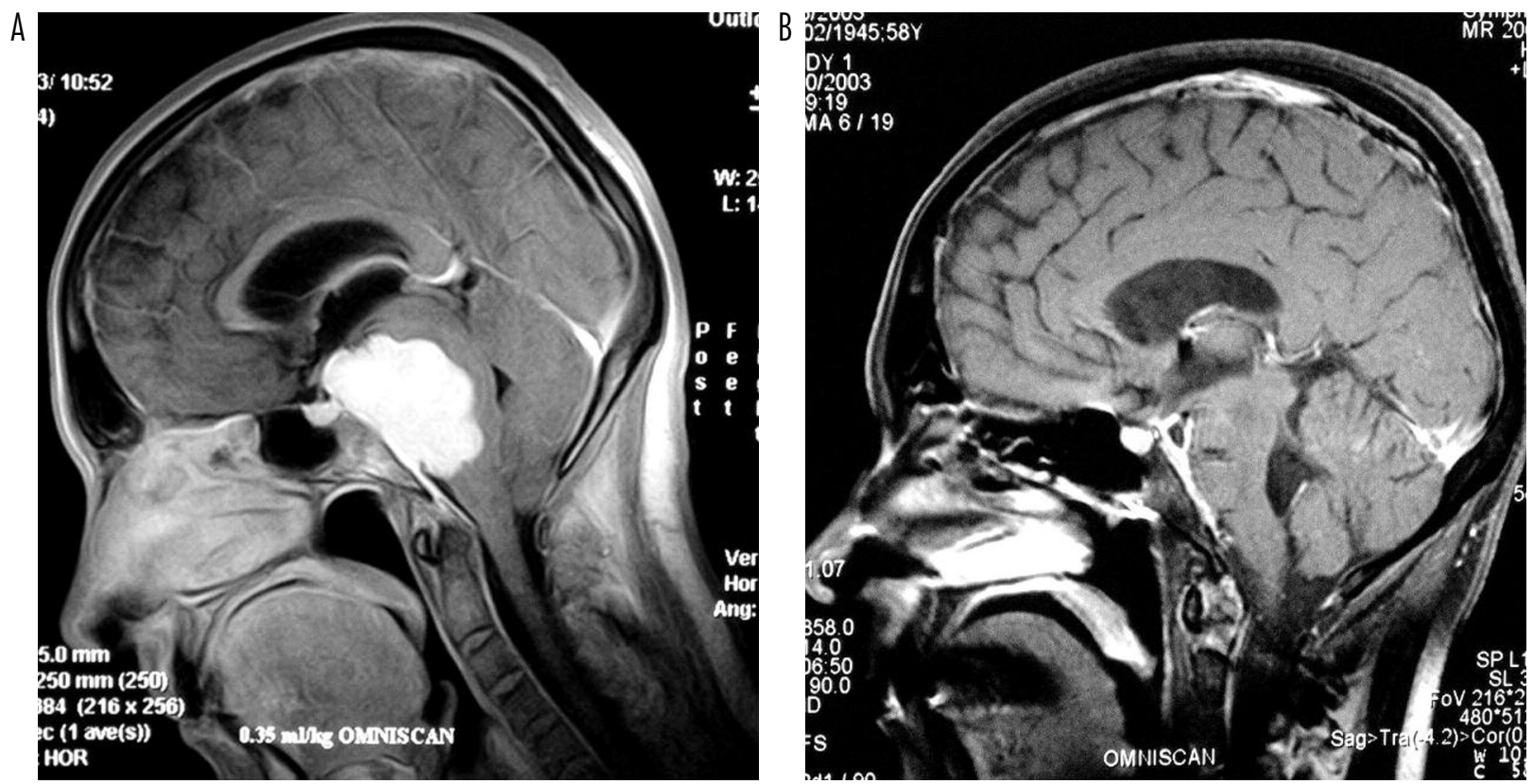

Fig. 3. Meningioma of upper and middle part of the clivus and petrous pyramid on the left (patient no. 10, A.M., aged 58). Patient presented with disequilibrium and unilateral, left-sided deafness, decreased sensation on the left side of the face and trochlear nerve paralysis on the left. Tumour volume $61 \mathrm{~cm}^{3}$. Complete petrosal approach was implemented with radical resection of the tumour and coagulation of attachment. Postoperative cavity after pyramid dissection was filled with autogenous fat tissue. Postoperative, transient consciousness disturbances and respiratory insufficiency along with profound right-sided hemiparesis, aphasia, disequilibrium and facial nerve palsy were found. Follow-up time - 98 months; (A) preoperative sagittal MRI, (B) postoperative sagittal MRI

In 9 patients, whose tumour volume exceeded $40 \mathrm{~cm}^{3}$, angiography was performed. In 3 cases, preoperative embolization was subsequently performed due to rich pathological vascularisation of the tumours. For the remaining 23 cases where no preoperative embolization had seemed necessary, we encountered 6 highly vascular tumours that required extensive haemostasis during resection. Three of these tumours were adherent to the brainstem pia. The majority of the tumours (21 cases) were firm; still it rendered no technical difficulties during resection. Two of the 

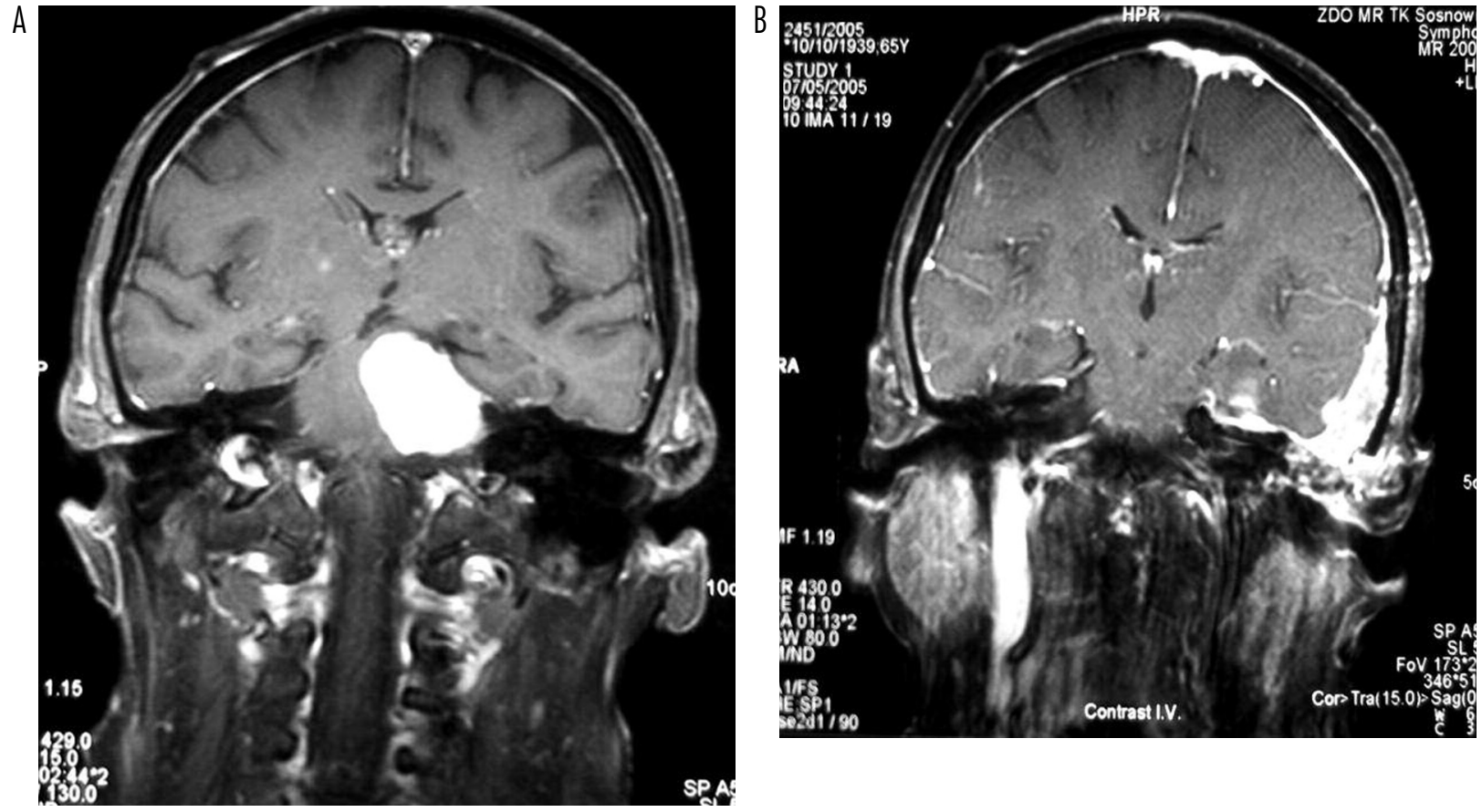

Fig. 4. Meningioma of upper and middle part of the clivus and petrous pyramid on the left encasing left Meckel's cave and cavernous sinus, spanning up to the tentorial incisure (patient no. 21, K.M., aged 65). Patient presented with profound right-sided hemiparesis and discrete left abducens nerve palsy. Tumour volume $50 \mathrm{~cm}^{3}$. Combined petrosal approach was implemented. Tumour was radically removed from the posterior fossa with attachment coagulation. Tumour within Meckel's cave was reduced while the cavernous part of the tumour remained untouched. Postoperative course was complicated by transient consciousness disturbances and respiratory insufficiency that subsided within 5 days along with the reduction of left temporal lobe and brainstem oedema. Right-sided hemiparesis diminished significantly with postoperative rehabilitation. Follow-up time - 72 months; (A) preoperative coronal MRI, (B) postoperative coronal MRI

tumours were partially very hard. Conversely, 5 of the tumours were definitely lax and the ease of resection rendered good clinical outcome after treatment.

We did not achieve Simpson grade I resection in any of the cases. In 18 cases $(69.3 \%)$, tumours were dissected radically with subsequent coagulation of the attachment. In one case, we were forced to abandon the coagulation of the attachment owing to significant bleeding from the basilar plexus. In the remaining 7 cases $(26.9 \%)$, only partial resection was achieved. In 3 patients, we elected not to remove intracavernous parts of the tumour since patients showed no clinical signs of tumour in this region. In 3 other cases, lack of radicalness arose from the adherence of the tumour to the brainstem. In one patient both aforementioned causes resulted in non-radical resection.

Follow-up times varied from 12 to 145 months (mean: 78 months, SD: 34 months). We noticed neither the progression of the partially resected tumours nor recurrence of radically resected tumours during follow-up. One of the patients passed away for unrelated reasons almost 6 years after surgery.

Comparison of the functional capacities of the patients on admission and on discharge measured with the Kar- nofsky performance scale (Table 3 ) revealed unchanged condition in $26.9 \%$ (7 patients) and deterioration in $65.4 \%$ (17 patients) of cases. Two patients died, which accounted for $7.8 \%$ of our cohort. Similar comparisons of the functional capacities of the patients on admission and during follow-up no earlier than 6 months after surgery showed improvement in $34.6 \%$ (9 patients), unchanged condition in $46.2 \%$ (12 patients) and deterioration in $11.5 \%$ (3 patients) of patients.

\section{Discussion}

Literature reviews by Al-Mefty et al. [10] and Samii et al. [11] proved that prior to 1970 only one report of radical resection of the clival meningioma was published and mortality of the patients treated for them exceeded $50 \%$. Recently, however, the introduction of new, extensive surgical techniques in skull base surgery have enabled more radical treatment along with a systematic reduction of mortality.

A number of reports [4,7,10-19] point out that the clinical status of patients with CM results from brain- 

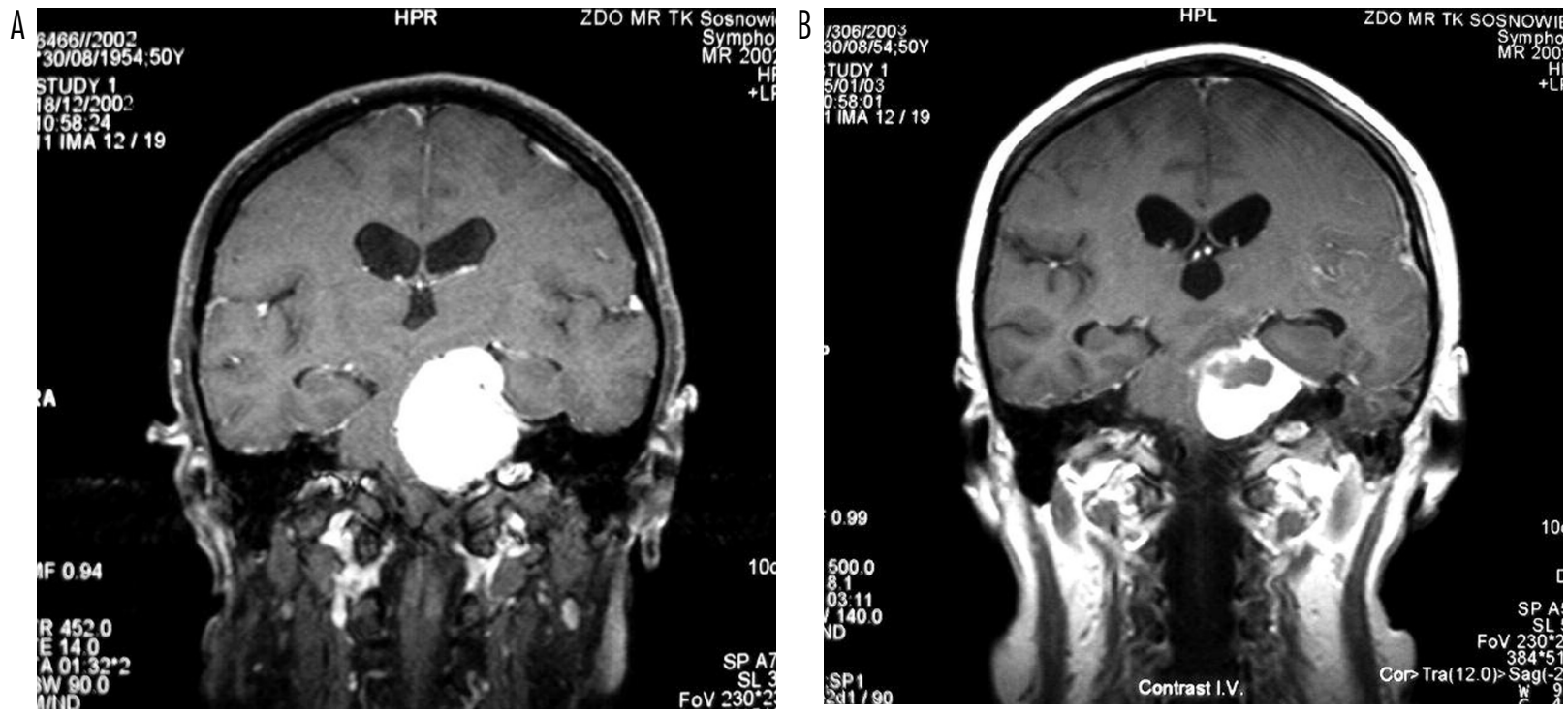

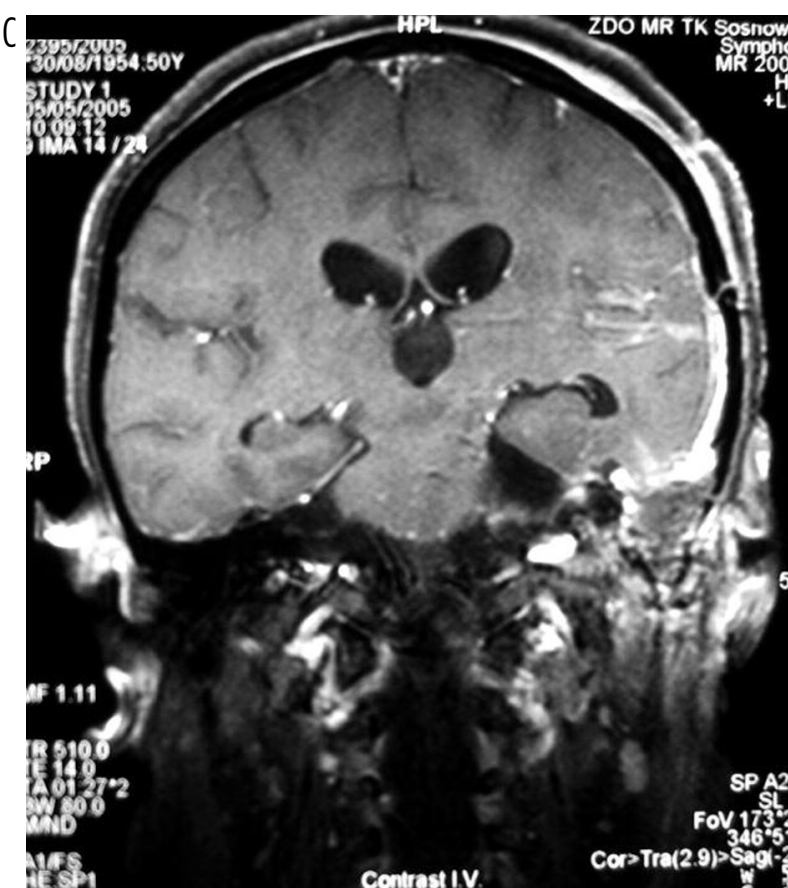

stem, cerebellar and $\mathrm{CN}$ involvement. In some cases, intracranial hypertension also occurs. Gait disturbances are related to both spastic, pyramidal hemiparesis and cerebellar ataxia. Rarely, hemidysaesthesia occurs. The olfactory nerve is the only CN that was not reported as affected by these tumours. On the other hand, trochlear and vestibulocochlear nerves are the most commonly involved. Small tumours present few symptoms. Conversely, large tumours usually present with a plethora of symptoms; still it is possible to find patients with large tumours that present with almost no symptoms.
Fig. 5. Meningioma of upper and middle part of the clivus and petrous pyramid on the left encasing left Meckel's cave, spanning above the tentorial incisure into the interpeduncular fossa (patient no. 11, B.B., aged 50). Patient presented with right-sided hemiparesis, disequilibrium and trigeminal neuralgia that was resistant to pharmacological treatment. Tumour volume $60 \mathrm{~cm}^{3}$. During the first stage of the treatment fronto-temporo-orbitozygomatic approach was implemented that enabled dissection of the upper part of the tumour. Following surgery right-sided hemiparesis deteriorated into hemiplegia with concomitant consciousness disturbances followed by aphasia. Left temporal lobe oedema was also present. Within three months after initial surgery the patient improved and underwent secondary surgery via posterior petrosal approach. Radical resection of the tumour and coagulation of attachment was achieved. Likewise, postoperative right-sided hemiplegia with concomitant abducens nerve palsy occurred. Simultaneously, trigeminal neuralgia subsided. Following 6 months rehabilitation, right-sided hemiparesis diminished to a degree smaller than initial, prior to the treatment. Other deficits subsided. Follow-up time - 98 months; (A) preoperative coronal MRI, (B) coronal MRI following initial surgery, (C) coronal MRI following final surgery

A good example is patient no. 22, whose tumour volume reached $54 \mathrm{~cm}^{3}$ while resulting only in mild ataxia.

The most serious obstacles during CM surgery are associated with their relation to the brainstem. The level of tumour-related compression on the brainstem quite often does not translate into the severity of the disturbances of both ascending and descending long tracts [7]. Our observations concur with this notion. Hemiparesis, which ought to be related to the tumour influence on the brainstem, did not occur in cases with the largest tumours causing the most significant compres- 
sion on the brainstem. Still, neurological outcome of the surgical resection of these tumours largely depends on the their relation to the brainstem. Sekhar et al. [20] described three degrees of tumour interaction with the brainstem: in the first degree the arachnoid of the brainstem is preserved, in the second it is partially destroyed while in the third the pia of the brainstem is infiltrated by the tumour. Kawase et al. [14] specified the second degree as penetration of the meningioma into the subarachnoid space with encasement of the vessels whose branches supply the brainstem. The third degree is synonymous with blood-brain barrier disruption by the tumour, thus allowing the penetration of toxic substances produced by the tumour into the brainstem [20]. It results in the brainstem oedema that is clearly visible in T2-weighted MRI sequences in these cases $[5,6,14]$. There is a general consensus that the presence of this radiological phenomenon validates the decision to give up the attempts of radical resection of a given tumour $[5,6,14,20,21]$. Couldwell et al. [5] even suggest that a $4 \mathrm{~mm}$ layer of the tumour should be left on the surface of the brainstem.

There are two major blood supply sources for $\mathrm{CM}-$ the meningohypophyseal artery and the ascending pharyngeal artery $[15,17,18]$. The meningohypophyseal artery branches from the internal carotid artery in its cavernous segment close to the median curve. The tumours in question are supplied directly by the final branches of the meningohypophyseal artery, i.e. the tentorial artery (Bernasconi-Cassinari) and dorsal meningeal artery. The meningeal branch of the ascending pharyngeal artery that enters the cranial cavity via the foramen lacerum plays a similar role. Additional blood supply sources for $\mathrm{CM}$ arise from other branches of the internal carotid artery, external carotid artery, meningeal branches of the vertebral artery and small branches of the basilar artery [11]. Identification of the vascularisation of the tumour by the latter plays a similar role to the brainstem oedema found on MRI in the decision not to perform radical resection of the tumour. Another important stage of the treatment protocol is tumour embolisation in highly vascular cases. In our cohort, we implemented it three times. Follow-up angiography after embolisation showed significant reduction of tumour vascularity. One could guess that dissection of these tumours without embolisation could be much more difficult and result in severe neurological sequelae. The odds for preservation of important anatomical structures, cranial nerves in particular, are much lower when you struggle with severe haemorrhage.
CMs occupy the space between the skull base, brainstem, cerebellum, cerebellar tentorium and temporal lobe. Despite the localization of the tumour attachment the degree of the space sequester rendered by various tumours might be similar. This notion justifies the discussion of Meckel's cave and selected tentorial incisure meningiomas along with clival meningiomas. Various localisations of the attachment result in various directions of tumour growth, despite the fact that, at the time of the diagnosis, they occupy a similar location. On the other hand, different directions of the outgrowth result in different relations of cranial nerves to the tumour [7]. Variable topography of the trigeminal nerve in relation to meningiomas with a different location of the attachment is a particularly good example [6]. Meningiomas that originate in the upper clivus dislocate the trigeminal nerve root laterally while those that originate from Meckel's cave, the tentorial incisure or the apex of the pyramid do so medially. This information is of particular importance during tentorial incision. The trigeminal nerve dislocated laterally might be unexpectedly close to the superior petrosal sinus. Obliteration of the sinus along with the tentorial transsection might result in nerve injury.

Despite the fact that in our study we implemented similar methodology for tumour volume evaluation to the one described by Sekhar et al. [17], still we defined different numerical ranges for given categories. For our purposes small tumours were defined as smaller than $10 \mathrm{~cm}^{3}$, large as those ranging from 10 to $25 \mathrm{~cm}^{3}$, and gigantic as those exceeding $40 \mathrm{~cm}^{3}$. Sekhar et al. [17] considered tumours smaller than $0.5 \mathrm{~cm}^{3}$ as small, those ranging from 0.5 to $7.9 \mathrm{~cm}^{3}$ as mid-sized, tumours between 8.0 and $46.0 \mathrm{~cm}^{3}$ as large and over $47 \mathrm{~cm}^{3}$ as gigantic. In our opinion Sekhar's classification is of limited use for we found no tumours smaller than $0.5 \mathrm{~cm}^{3}$ in this region and tumours within the 8.0 to $46.0 \mathrm{~cm}^{3}$ range require different surgical approaches.

Surgical strategies in CM treatment depend on individual experience and preferences of individual authors as well as the size and location of the tumour. The consensus for small and mid-sized clival meningiomas comprises implementation of an anterior petrosal approach when they are found predominantly in the upper clivus, posterior petrosal when they dominate the middle portion of the clivus, and a partial transcondylar approach when they occupy mainly the lower portion of the clivus $[4,13,17,22]$. Some authors combine a posterior petrosal approach with a retrosigmoid approach with either preservation or dissection of the sigmoid sinus $[11,16]$. 
A complete petrosal approach is usually implemented in large tumours that occupy simultaneously two or all three sections of the clivus $[5,13,17,22]$. An alternate approach that facilitates hearing preservation and minimizes the risk of facial nerve injury is the combination of anterior and posterior petrosal approaches, i.e. a combined petrosal approach $[12,22]$. CMs that encase the tentorial incisure, and widespread in the middle fossa, interpeduncular fossa and parasellar region, are approached via a pterional approach [11], subtemporal-supratentorial approach [5] or fronto-temporo-orbito-zygomatic approach [17]. Any of these approaches, the last one in particular, might be implemented in the first stage of the surgical treatment whilst the second stage involves either a posterior or a complete petrosal approach [13]. Single-stage resection of very large tumours in this localization is rare. Javed and Sekhar in 10 cases [13] elected to combine a fronto-temporo-orbito-zygomatic approach with an extended subtemporal approach that involves resection of the condyloid process of the mandible followed by extensive resection of the petrous pyramid and the clivus with concomitant mobilization and translocation of the petrous part of the internal carotid artery. All CM cases with cavernous sinus involvement require a combination of one of the supratentorial approaches with either an intracavernous approach [5, $13,17]$ or with a posterior cavernous approach from Meckel's cave [23,24].

When we had begun the treatment of the patients later recruited into the current study we decided to base the treatment protocol on the aforementioned ideas. Subsequently, a retrospective analysis of collected data with particular attention paid to tumours' topography, their volume and surgical approach implemented allowed us to create an algorithm, which facilitates the selection of the surgical approaches in the treatment of CM. Small and mid-sized tumours, i.e. smaller than $25 \mathrm{~cm}^{3}$, with an attachment located above the line that connects both internal auditory meatuses, i.e. in the upper part of the clivus, justify the selection of the anterior petrosal approach (Fig. 1). Accordingly, tumours within the same volume range with the attachment below the same line, i.e. in the middle portion of the clivus, justify the selection of the posterior petrosal approach (Fig. 2). Disciples of the classical approaches in the first of the aforementioned tumour groups suggest the subtemporal-transtentorial approach; they also advocate the retrosigmoid approach in the latter group. While such opinions, under certain conditions, might be acceptable for mid-sized tumours, they are hard to agree with in small tumours. Upon resec- tion, mid-size tumours create space for the surgeon that facilitates surgical manoeuvres, while small tumours, i.e. with the volume below $10 \mathrm{~cm}^{3}$, do not. Therefore, in order to access a small tumour via one of the classical approaches, one has to compress the temporal lobe, cerebellum or brainstem, thus increasing the risk of their injury. Large and gigantic tumours, that is larger than $25 \mathrm{~cm}^{3}$, with significant supratentorial expansion require a two-staged approach (Fig. 5). The first stage usually involves a fronto-temporo-orbito-zygomatic approach [25], which enables complete removal of the supratentorial section and upper parts of the infratentorial section of the tumour. The second stage is a continuation of resection based on either a posterior petrosal approach, its combination with an anterior petrosal approach, or a complete petrosal approach. The decision whether a particular approach should be selected depends on the localization of the tumour and the radicalness of the first stage. Large and gigantic tumours without or with minimal supratentorial expansion justify the implementation of a combined petrosal approach (Fig. 4) or complete petrosal approach in selected cases of patients without functional hearing on the tumour side (Fig. 3).

Reports on outcomes of the surgical treatment of CMs by Al-Mefty [12], Glasscock [18], Fukushima [5], Samii [21] and Sekhar [17] were based on their own cohorts of 7, 4, 109, 36 and 41 cases, respectively. Mortality reported by these authors varied from 0 to $8 \%$ with the percentage of radical resections around $70 \%$. The incidence of hemiparesis related to postoperative brainstem injury did not exceed $14 \%$. Cranial nerve deficits occurred in no less than $33 \%$ and no more than $71 \%$ of the patients. A significant percentage of early postoperative deficits subsided later on. Trochlear, abducens and facial nerves were affected most often. Samii [21] divided his patients into three groups: capable of resuming preoperative activities (56\%), independent yet unable to resume preoperative activities (28\%), and those who require constant care $(16 \%)$.

Two patients, i.e. $7.8 \%$ out of 26 patients, in our cohort died; this mortality places our results within the 0 to $8 \%$ range cited above. The first death was directly related to cardiological conditions that had been present preoperatively, which suggests preoperative evaluation that was not rigorous enough. Clival meningiomas and treatment modalities eventually implemented render such a load on the patient that with other, preexisting conditions a favourable outcome of the therapy is difficult to achieve. Preoperative symptomatology of the second case was dominated by intracranial hypertension 
with an estimated tumour volume around $60 \mathrm{~cm}^{3}$. In this case, based on previously mentioned rules, we left a layer of the tumour on the brainstem owing to the pia infiltration. Still, brainstem decompression was significant and the patient succumbed to brainstem insufficiency. It is possible that staged treatment would allow us to achieve better results.

Radical resections were achieved in $69 \%$ of cases, which is in concurrence with abovementioned reports. Transient consciousness and ventilation disturbances occurred in $17 \%$ of the patients. Hemiparesis resulting from brainstem or temporal lobe injury and oedema was present in $38 \%$ of cases, which is more often than in the literature. The incidence of particular cranial nerve deficits varied from 12 to $68 \%$, with the facial nerve most frequently involved. The degree of palsy and cranial nerve dysfunctions did not differ significantly between preoperative examination and examination on discharge. Follow-up examination, however, performed no earlier than 6 months after discharge, showed significant improvement. This observation also concurs with the others.

Aziz et al. [4] concluded in their study that the Simpson scale in its original version is not applicable for the assessment of radicalness of $\mathrm{CM}$ resection. They suggested a modification of the scale that rejects points I and V, keeps points II and III, and distinguishes 3 variants in point IV. These variants concern the situation when the remaining part of the tumour is less than $10 \%$ of the initial volume, from 10 to $50 \%$ and over $50 \%$, respectively. All of the cases with more than $10 \%$ of the tumour remaining additionally take into account the degree of brainstem relaxation into the assessment of resection radicalness. The concept of Aziz et al. [4] raises doubts, however. First of all, even with radical resection of the tumour and good clinical outcome brainstem relaxation might be partial (Fig. 5C). The train of thought of the cited authors seems to be correct for all of the cases where the non-relaxed brainstem is still dislocated by the remaining portion of the tumour, yet no exception alike was ever mentioned. Next, the Simpson scale published 54 years ago [26] thanks to its explicitness imposes uniform standards of surgical treatment of all the meningiomas independent of their localization. Instead of proposing convoluted modifications of this scale, one has to admit that existing surgical techniques do not allow Simpson grade I resections of meningiomas of the petrous pyramid apex and the clivus.

Van Havenbergh et al. [19] conducted an analysis of the natural course of the disease in 21 cases of $\mathrm{CMs}$ that were not treated surgically either based on the lack of any neurological signs or symptoms owing to the incidental diagnosis of the tumour, serious co-morbidities or advanced age. The average follow-up time was less than 7 years. Two patients died from complications of a previously diagnosed skull base tumour. In $52 \%$ of cases the patient's status was stable, while $19 \%$ deteriorated over the years, losing at least 30 points on the Karnofsky performance scale. Moreover, the cited study undermined the view that a relationship exists between slower growth of these tumours and age or menopause. It also proved that small and mid-sized tumours grow faster than large ones. Nonetheless, Van Havenbergh et al. [19] still advise conservative treatment in elderly patients with small, asymptomatic tumours. Surgical intervention should be contemplated whenever tumour progression or neurological sequelae are found during follow-up $[19,22]$. It is also applicable to large tumours whenever found. Sekhar et al. [20] stress that occurrence of even a trace of any neurological symptoms in patients with small or mid-sized tumours justifies surgical intervention. Surgical treatment of CMs is an art of combining the radicalness of resection with the avoidance of permanent neurological deficits $[4,22]$. Nonradical resection results in tumour recurrence and therefore the need for reoperation that is, owing to existing adhesions, associated with much higher risk than the initial surgery [7]. Nevertheless, case reports exist that describe patients after non-radical resection with longterm, progression-free survival and excellent neurological outcomes [27]. It is particularly relevant for the elderly [13]. Stereotactic radiotherapy plays an important role in the treatment of patients following nonradical resection. Still, it is only a palliative modality $[27,28]$. It should not be implemented prior to surgical treatment [29].

Coulwell et al. [5] and Little et al. [22] suggest that intracavernous parts of meningiomas of the clivus and surrounding structures should be dissected only when they result in eye movement disturbances. Asymptomatic cases should undergo adjuvant radiotherapy followed by regular imaging studies. Unfortunately, the remaining intracavernous parts of the tumours at hand, either electively left or non-radically dissected, often give rise to recurrence [5].

In order to sum up the considerations on the clinical picture of patients whose treatment involved petrosal approaches - anterior, posterior, complete and combined - one should stress a few facts. The majority of the patients deteriorated clinically immediately after 
surgery and during early convalescence after implementation of these approaches. There are at least three possible causes: the first is aggravation of the neurological deficits related to the ongoing neoplasm; the second relates to the occurrence of new neurological deficits that arise from the interference with neural and vascular structures, which did not show any dysfunctions despite their involvement by the tumour prior to the treatment; and the third is related to the deficits that arise from anatomical conditions of the selected approach. Objectivity of the assessment of petrosal approaches requires separate analysis of the clinical symptomatology prior to surgery on one hand and after postoperative rehabilitation on the other, along with additional analysis of deficits related to the tumour and truly iatrogenic deficits that arise from the selected approach. Long-term follow-up facilitated the detection of recovery related to both individual neurological deficits and general condition of the patients. Functional capacity assessment according to the Karnofsky performance scale revealed improvement usually by $10 \%$, rarely by $20 \%$, and in two cases even by $30 \%$. There is agreement in the literature that the introduction of petrosal approaches improved surgical outcomes when compared to classical approaches. It is particularly relevant to brainstem and cranial nerve-related disturbances that arise from tumour topography. Iatrogenic deficits related to petrosal approaches involve hearing, facial nerve function and the temporal lobe. An anterior petrosal approach, correctly performed, poses a minor threat to hearing and facial nerve function. Deficits might arise when petrous pyramid resection is extensive, which results in injury to the cochlea and internal auditory meatus' contents. Similarly, the posterior petrosal approach should not result in hearing or facial nerve deficits, but still the risk is much higher for it arises from the possible injury of middle ear structures and the facial nerve in its mastoid part. Implementation of the complete petrosal approach always results in hearing deficits; moreover, posterior reposition of the facial nerve often leads to either transient or permanent deficits of its function; amputation of the greater petrosal nerve is also necessary. In patients with functional hearing on the affected side an alternative method of treatment involves a combined petrosal approach, i.e. a combination of anterior and posterior petrosal approaches. It enables hearing preservation and does not expose the facial nerve. Unfortunately, it dose not ensure surgical conditions comparable to those provided by a complete petrosal approach. Deficits related to temporal lobe injury in cases treated with a petrosal approach arise from either the compression of the lobe or the injury of its venous drainage. Venous drainage injury does not occur when the anterior petrosal approach is applied. Its occurrence is highly dependent on anatomical configuration of the venous system. The degree of temporal lobe compression necessary for petrosal approaches' performance diminishes with the increase of petrous pyramid resection in those approaches. The anterior petrosal approach, in comparison to the other two approaches, requires the most excessive retraction of the temporal lobe whilst petrous pyramid resection is the smallest. Retraction of the temporal lobe is smaller with the posterior petrosal approach, while it is negligible with combined and complete petrosal approaches. The dimensions of the surgical corridor offered by petrosal approaches relates to the degree of retraction of the temporal lobe and cerebellum for the extent of the resection of bony structures is constant and contained in the concept of a given approach. Posterior retraction of the cerebellar hemisphere along with rostral retraction of the temporal lobe expands this corridor but it might result in more severe and permanent neurological deficits. In other words, while performing petrosal approaches one should not abuse temporal lobe and cerebellar hemisphere traction; moreover, their compression ought to be limited to the necessary minimum as well. The aforementioned algorithm for selection of surgical approaches in the treatment of apex and clival meningiomas originates from these considerations. Among other things, this algorithm assumes that anterior and posterior petrosal approaches should not be implemented whenever the tumour volume exceeds $25 \mathrm{~cm}^{3}$. Importantly, it does not mean that it is impossible technically to remove larger, properly localized meningiomas via these approaches but rather that it may permanently deteriorate the patients' condition.

\section{Conclusions}

1. Implementation of petrosal approaches in the surgical treatment of meningiomas of the upper and middle parts of the clivus and surrounding structures allows a high percentage of radical resections with favourable neurological outcome and relatively low mortality.

2. Meningiomas in this group with a volume smaller than $25 \mathrm{~cm}^{3}$ are accessible with either an anterior or a posterior petrosal approach while larger ones are accessible with a combined or complete petrosal approach. 


\section{Disclosure}

Authors report no conflict of interest.

\section{References}

1. Yasargil M.G., Mortara R.W., Curcic M. Meningioma of basal posterior cranial fossa. In: Krayenbühl H. [ed.]. Advances and technical standards in neurosurgery. Springer, Wien 1980, pp. 1-115.

2. Al-Mefty O. Operative atlas of meningiomas. Lippincott-Raven, Philadelphia 1997, pp. 209-210.

3. Ware M.L., Pravdenkova S., Erkmen K., et al. Petroclivial and upper clivial meningioma I: an overview of surgical approaches. In: Lee J.H. [ed.]. Meningiomas. Springer, London 2008, pp. 403-414.

4. Aziz K., Sanan A., van Loveren H., et al. Petroclival meningiomas: predictive parameters for transpetrosal approaches. Neurosurgery 2000; 47: 139-152.

5. Couldwell W., Fukushima T., Giannotta S., et al. Petroclival meningiomas: surgical experience in 109 cases. J Neurosurg 1996; 84: 20-28.

6. Kawase T. Technique of anterior transpetrosal approach. Oper Tech Neurosurg 1999; 2: 10-17.

7. Kawase T., Shiobara R., Toya S. Anterior transpetrosal-transtentorial approach for sphenopetroclival meningiomas: surgical method and results in 10 patients. Neurosurgery 1991; 28: 869-876.

8. Ladzinski P., Majchrzak H., Kaspera W., et al. Meningiomas of the anterior portion of the craniovertebral junction: early and long term results of surgical removal using partial transcondylar approach. Neurol Neurochir Pol 2011; 46: 205-215.

9. Barnett S.L., D’Ambrosio A.L., Agazzi S., et al. Petroclivial and upper clivial meningioma III: combined anterior and posterior approach. In: Lee J.H. [ed.] Meningiomas. Springer, London 2008, pp. 425-432.

10. Al-Mefty O., Fox J., Smith R. Petrosal approach for petroclival meningiomas. Neurosurgery 1988; 22: 510-517.

11. Samii M., Ammirati M., Mahran A., et al. Surgery of petroclival meningiomas: report of 24 cases. Neurosurgery 1989; 24 12-17.

12. Cho Ch., Al-Mefty O. Combined petrosal approach to petroclival meningiomas. Neurosurgery 2002; 51: 708-718.

13. Javed T., Sekhar L. Surgical management of clival meningiomas. Acta Neurochir Suppl. 1991; 53: 171-182.

14. Kawase T., Shiobara R., Toya S. Middle fossa transpetrosaltranstentorial approaches for petroclival meningiomas. selective pyramid resection and radicality. Acta Neurochir (Wien) 1994; 129: 113-120.

15. Mayberg M., Symon L. Meningiomas of the clivus and apical petrous bone. J Neurosurg 1986; 65: 160-167.

16. Nassif P., Hankinson H., Horn K. The middle fossa transpetrous approach: experience with 13 cases. Skull Base Surg 1997; 7: 5-14.

17. Sekhar L., Jannetta P., Burkhart L., et al. Meningiomas involving the clivus: a six-year experience with 41 patients. Neurosurgery 1990; 27: 764-781.
18. Thedinger B., Glasscock III M., Cueva R. Transcochlear transtentorial approach for removal of large cerebellopontine angle meningiomas. Am J Otol 1992; 13: 408-415.

19. van Havenbergh T., Carvalho G., Tatagiba M., et al. Natural history of petroclival meningiomas. Neurosurgery 2003; 52: 55-64.

20. Sekhar L., Swamy N., Jaiswal V., et al. Surgical excision of meningiomas involving the clivus: preoperative and intraoperative features as predictors of postoperative functional deterioration. J Neurosurg 1994; 81: 860-868.

21. Samii M., Tatagiba M. Experience with 36 surgical cases of petroclival meningiomas. Acta Neurochir (Wien) 1992; 118: 27-32.

22. Little K., Friedman A., Sampson J., et al. Surgical management of petroclivial meningiomas: defining resection goals based on risk of neurological morbidity and tumor recurrence rates in 137 patients. Neurosurgery 2005; 56: 546-559.

23. Kawase T., van Loveren H., Keller J.T., et al. Meningeal architecture of the cavernous sinus: clinical and surgical implications. Neurosurgery 1996; 39: 527-536.

24. Sekhar L., Javed T., Jannetta P. Petroclivial meningioma. In: Sekhar L., Janecka I. [eds.]. Surgery of cranial base tumors. Raven Press, New York 1993, pp. 605-659.

25. Ladzinski P., Maliszewski M., Kaspera W., et al. Dostęp czołowo-skroniowo-oczodołowo-jarzmowy - analiza techniki operacyjnej w oparcie o symulacje na zwłokach. Neurol Neurochir Pol 2010; 44: 492-503.

26. Simpson D. The recurrence of intracranial meningiomas after surgical treatment. J Neurol Neurosurg Psychiatry 1957; 20: 22-39.

27. Ciric I., Landau B. Tentorial and posterior cranial fossa meningiomas: operative results and long-term follow-up: experience with twenty-six cases. Surg Neurol 1993; 39: 530-537.

28. Mathiesen T., Lindquist Ch., Kihlström L., et al. Recurrence of cranial base meningiomas. Neurosurgery 1996; 39: 2-9.

29. Samii M., Rosahl S., Tatagiba M. Microsurgical removal of a petrous apex meningioma after stereotactic radiation: technical case report. Neurosurgery 2001; 49: 216-220. 